Rev. salud pública. 10 (1):85-93, 2008

\title{
A Preliminary Statistical Study of Whether Pesticide use Could be Related to birth defects in a rural area of Venezuela
}

\section{Estudio estadístico preliminar sobre uso de plaguicidas y defectos de nacimiento en un área rural de Venezuela}

\author{
Maritza Rojas ${ }^{1,2,}$ Olga Agreda ${ }^{2}$ and Saba Infante ${ }^{3}$
}

\author{
1 MRM-CONSULTOX. Valencia, Venezuela. rojas.m@intercable.net.ve \\ 2 Centre for Toxicological Investigations (CITUC), University of Carabobo, Valencia, \\ Venezuela. otagreda@cantv.net \\ 3 School of Science and Technology (FACYT), University of Carabobo, Valencia, Venezuela. \\ sinfante@uc.edu.ve
}

Received $9^{\text {th }}$ August $2007 /$ Sent for Modification $9^{\text {th }}$ January 2008/Accepted $14^{\text {th }}$ January 2008

\section{ABSTRACT}

Objectives This study was carried out in response to health authorities' concerns regarding what they considered to be a "high proportion" of birth defects (BD) in a rural Venezuelan state as the preliminary step towards subsequent health assessment regarding exposure to pesticides and possible association with registered BD.

Methods This was a cross-sectional descriptive study. Generalised linear modelling (GLM) was used for relating BD with county of origin and the date of the events. Pesticideuse reports were used for assessing exposure to pesticides. Infants' medical records for 1999-2002 were obtained from the state hospital. The study group consisted of 108 BD cases from 8 municipalities.

Results The cardiovascular system had the highest frequency $(20,4 \%)$ of BD, followed by the gastro-intestinal (18,5\%) and urogenital systems (10,2\%). Anilides were the most frequently used group of liquid pesticides (39,8 \%), followed by phosphonomethyl-glycine $(19,6 \%)$. The most commonly used solid pesticides were organophosphates (54,4\%). GLM revealed some significant results; the number of $\mathrm{BD}$ increased exponentially throughout the years being studied.

Conclusions A causal association between BD and potential pesticide exposure could not be demonstrated due to data limitations. A more in-depth exposure assessment and epidemiological studies are still needed for characterising the risk of exposure to pesticides in terms of birth outcomes in the area being studied.

Key Words: Congenital malformation, pesticide, exposure, Venezuela (source: $\mathrm{MeSH}$, NLM).

RESUMEN

Objetivos En respuesta a la preocupación de autoridades de salud en lo que consideraban un "alto índice de BD" en un Estado rural en Venezuela, se condujo un 
estudio preliminar para una evaluación posterior relacionada con los BD registrados y su posible asociación con exposición a plaguicidas.

Métodos Estudio descriptivo de corte transversal. Se usó un modelo linear generalizado (GLM) para asociar BD con municipio de origen y fecha del evento. Para evaluar la exposición a plaguicidas, se usaron los registros de ventas. Se obtuvieron los registros médicos del Hospital estadal (1999-2002). El Grupo estudiado estuvo conformado por 108 casos de 8 municipios.

Resultados El sistema cardio-vascular resultó con la frecuencia más alta de BD $(20,4 \%)$, seguido por el gastro-intestinal $(18,5 \%)$ y el urogenital $(10,2 \%)$. El grupo más utilizado de plaguicidas líquidos fue el de las anilidas $(39,8 \%)$ seguido por fosfono-metil-glicina $(19,6 \%)$. Los sólidos mas empleados fueron los organofosforados (54,4 \%). El GLM mostró algunos resultados significantes observándose que el número de $\mathrm{BD}$ aumentó exponencialmente a través de los años en estudio.

Conclusiones Debido a las limitaciones de los datos, no se pudo demostrar una asociación entre BD y exposición potencial a plaguicidas. Se requiere un estudio de exposición y epidemiológico más profundo para caracterizar riesgo de exposición a plaguicidas en términos de producción de malformaciones congénitas en el área.

Palabras Clave: Anomalías, exposición a plaguicidas, Venezuela (fuente: DeCS, BIREME).

$\mathrm{V}$ enezuela (like other developing countries) has serious problems due to pesticides' environmental and occupational effects; it is also limited in regulating their use and enforcing health and safety measures (1-3).Pesticides' developing toxicity may affect human reproduction; this has been shown in numerous epidemiological studies associating exposure to pesticides at work or in the home with an increased risk of several types of congenital malformations occurring, such as spontaneous abortion, growth retardation, structural birth defects or functional deficits (4-10).

Some health authorities have been concerned about what they consider to be a "high proportion" of congenital birth defects (BD) in a farming state in Venezuela where high amounts of pesticides are used. They have also been concerned about the possible association between parents' exposure to pesticides and the occurrence of such BD. This article arose from a preliminary investigation in response to these concerns.

Congenital malformations registered at the San Carlos state hospital were thus characterised, as were the type of pesticides being used in the area and an attempt made to see whether pesticide use could be associated with the aforementioned increased risk of adverse pregnancy and birth outcomes in the 
Venezuelan state of Cojedes. This preliminary investigation identified the pesticides used and BD records as the preliminary step towards a subsequent health assessment study regarding pesticide exposure and its possible association with registered congenital malformations, thereby leading to better control and preventative exposure measures being taken.

\section{METHODS}

The study was carried out in the rural Venezuelan state of Cojedes. The investigation included a review of infant medical records and potential parental exposure to pesticides. The data regarding congenital BD consisted of records obtained from the registrar's department at the San Carlos hospital in the capital of the state of Cojedes (1999-2002) including mothers' data (name, age, address, occupation, age at conception, smoking, history of illness (diabetes, hypertension), the number of pregnancies, history of spontaneous abortion, medicines used), type of BD, babies' data (name, date of birth, gender, gestational age, cephalic circumference, size, weight, etc).

A total of 119 BD records were reviewed, covering January 1999 to December 2002. Eleven cases were excluded from the analysis because important data was missing; 108 cases (68 male, 40 female) were then studied. Congenital malformations were categorised according to CIE-10 (11).

A list of the pesticides used for agricultural applications from 1999-2001 was obtained from the main retailers and the Ministry of Agriculture's regional office containing information about commercial name, active ingredients, formulation and amount sold. No accurate information regarding pesticides sold during 2002 could be found. 2001 information was taken based on the presumption that pregnancy lasts 9 months and that most parents' potential exposure to agrochemicals (having children born during 2002) must have occurred in that year. Pesticides' common names (12), the Pesticide Action Network Database (13) and the Venezuelan Agricultural and Livestock Index, 2005 (14) were consulted for categorising agents into groups having similar physicochemical properties.

Statistics:

This was a cross-sectional, descriptive study. Generalised linear modelling (GLM) was used for relating hospital-registered cases of BD with their county of origin and the year when they were reported. The Poisson regression statistical model was used for estimating the relationship between BD and 
county of origin, thereby correlating risk factors and health indicators. Poisson regression and other types of GLM (15) have contributed towards developing association tools including information provided by geographical units (counties in this case) regarding risk factors. Analysing diseases rates takes the number of cases of a particular disease/event $\left(Y_{i}\right)$ and the specific area $\left(A_{i}\right)$ where the event occured into account. The set of areas $\left\{A_{i}\right\}, i=1, \ldots, n$ represents a partition of the region being studied. Supposed Poisson distribution of events is $\left(\mathrm{Y}_{\mathrm{i}}\right)$. As the events (BD) in this study were considered to be "rare" and the Poisson distribution represented a good approximation of binomial distribution then it could be deduced that the risks in each county had a Poisson distribution. Local variability of BD/counties were thus modelled as follows: $\mathrm{Y}_{\mathrm{i}} \sim$ Poisson $\left(\lambda_{i}\right)$, independently for $i=1, \ldots, n$; where $\lambda_{i}$ (the number of expected cases per county) represented the parameter of interest, called relative risk. This estimated a high or low probability of the event being studied in area i. $Y_{1}, Y_{2}, \ldots, Y_{n}$, represented the number of $\mathrm{BD}$ occurring in each county with $\mathrm{i}=1,2, \ldots, \mathrm{n}$. These tendencies can be modelled by establishing a relationship explaining how relative risk $\left(\lambda_{i}\right)$ varied in each county. If $\lambda_{i}=i^{\beta}$, then such relationship was equivalent to considering a link function: $g(\lambda \mathrm{i})=\log (\mathrm{i}) \beta$, i.e. we have $\mathrm{g}\left(\lambda_{\mathrm{i}}\right)=\mathrm{X}_{\mathrm{i}}^{\mathrm{T}} \beta \mathrm{GLM}$, where $\log (i)=\mathrm{X}_{\mathrm{i}}^{\mathrm{T}}$ contained the covariates being measured in each county (date of event, gender of children suffering BD, etc). As the geographical pattern was known, GLM was used for proving the hypothesis of a correlation between BD, county and date of event, as follows:

$g\left(\lambda_{i}\right)=\beta_{0}+\beta_{1}$ county $_{i}+\beta_{2}$ county $_{i}^{2}+\beta_{3}$ date $_{i}+\beta_{4}$ county $_{i}{ }^{*}$ date $_{i}+\beta_{5}$ county $_{i}{ }^{2 *}$ date $_{\mathrm{i}}+\varepsilon_{\mathrm{i}}$

Where $g\left(\lambda_{i}\right)=$ number of BD/county.

\section{RESULTS}

Table 1 gives the study population's characteristics. Table 2 presents the distribution of children having congenital malformations according to county of origin, date of birth and gender. Table 3 describes the distribution of children having congenital malformations according to type of malformation and year (1999-2002) and Table 4 describes congenital malformation according to the type of system suffering such malformation. BD prevalence was 0,76 \% for 1999, 0,39 \% for 2000, 0,97 $\%$ for 2001 and $1,18 \%$ for 2002, giving a $0,67 \%$ average over the 4 year period.

Anilides was the most frequently used liquid pesticide group (39,8\%) followed by phosphono-methyl-glycine (19,6 \%), pyridines (6,8 \%) and pyrethroids (6,3 $\%)$. Solid pesticides more common used were organophosphates $(54,4 \%)$, 
followed by highly toxic carbamates (11,9\%) and urea and related compounds $(11,7 \%)$.

As mentioned, one of the main objectives of the study was to analyze the potential association between BD and pesticides use in Cojedes State. Due to lack of important data we could not measure such association. However, we correlated number of BD with their incidence in each county. Using the GLM and considering the Poisson link-function (from the R statistical package), our results led to proving the $\mathrm{H}_{\mathrm{o}}: \beta_{j}=0$ hypothesis against $\mathrm{H}_{\mathrm{a}}: \beta_{j} \neq 0$, for $\mathrm{j}=1,2, \ldots . ., \mathrm{n}$. In this case, the following relationships with $\mathrm{BD}$ proved statistically significant: county; county*county; county*date and county*county*date (Table 5).

Table 1. Characteristics of the study population

\begin{tabular}{|c|c|c|c|c|}
\hline Variable & $\mathrm{N}$ & $\%$ & Mean \pm SD & Range \\
\hline \multicolumn{5}{|l|}{ County of origin } \\
\hline San Carlos & 50 & 46,3 & NA & NA \\
\hline Other counties & 34 & 31,5 & NA & NA \\
\hline No information & 24 & 22,2 & NA & NA \\
\hline \multicolumn{5}{|l|}{ Mothers' data } \\
\hline Age (years) & 108 & 100 & $24 \pm 6,36$ & $15-41$ \\
\hline Gestational age (weeks) & 108 & 100 & $38,06 \pm 2,97$ & $28-43$ \\
\hline \multicolumn{5}{|l|}{ Children's data } \\
\hline Size $(\mathrm{cm})$ & 108 & 100 & $50,4 \pm 4,80$ & $32-60$ \\
\hline Weight (grams) & 108 & 100 & $3027,96 \pm 680,81$ & $1240-4700$ \\
\hline \multicolumn{5}{|l|}{ Mothers' health } \\
\hline $\begin{array}{l}\text { Mothers having suffered one } \\
\text { abortion }\end{array}$ & 3 & 2,7 & NA & NA \\
\hline $\begin{array}{l}\text { Mothers having suffered two } \\
\text { abortions }\end{array}$ & 1 & 0,9 & NA & NA \\
\hline Mothers suffering from diabetes & 2 & 1,79 & NA & NA \\
\hline $\begin{array}{l}\text { Mothers suffering from } \\
\text { hypertension }\end{array}$ & 4 & 3,57 & NA & NA \\
\hline Mothers who smoked & 3 & 2,7 & NA & NA \\
\hline
\end{tabular}

NA: Not applicable

Table 2. Distribution of children having congenital malformations according to county of origin, date of birth and gender

\begin{tabular}{|c|c|c|c|c|c|c|c|c|}
\hline \multirow{2}{*}{ County } & \multirow{2}{*}{1999} & \multirow{2}{*}{2000} & \multirow{2}{*}{2001} & \multirow{2}{*}{2002} & \multirow{2}{*}{ Male } & \multirow{2}{*}{ Female } & \multicolumn{2}{|c|}{ Total } \\
\hline & & & & & & & H & \& \\
\hline San Carlos & 7 & 7 & 18 & 18 & 29 & 21 & 50 & 46.3 \\
\hline Tinaco & 6 & 2 & 1 & 2 & 10 & 1 & 11 & 10.2 \\
\hline R. Gallegos & 5 & 1 & 2 & 3 & 8 & 3 & 11 & 10.2 \\
\hline Anzoategui & 1 & 1 & 1 & 1 & 2 & 2 & 4 & 3.7 \\
\hline Pao de SJB & 1 & 2 & 1 & 1 & 2 & 3 & 5 & 4.6 \\
\hline Ricaurte & 0 & 0 & 0 & 1 & 1 & 0 & 1 & 0.9 \\
\hline Tinaquillo & 1 & 0 & 0 & 0 & 0 & 1 & 1 & 0.9 \\
\hline Lima Blanco & 0 & 0 & 1 & 0 & 0 & 1 & 1 & 0.9 \\
\hline No information & 4 & 0 & 7 & 13 & 16 & 8 & 24 & 22.2 \\
\hline Total & 25 & 13 & 31 & 39 & 68 & 40 & $10 B$ & 100.0 \\
\hline
\end{tabular}


Table 3. Distribution of children having congenital malformations according to type of malformation and year. Cojedes state, 1999-2002

\begin{tabular}{|c|c|c|c|c|c|c|}
\hline \multirow{2}{*}{$\begin{array}{l}\text { Congenital } \\
\text { malformation }\end{array}$} & \multirow{2}{*}{1999} & \multirow{2}{*}{2000} & \multirow{2}{*}{2001} & \multirow{2}{*}{2002} & \multicolumn{2}{|c|}{ Total } \\
\hline & & & & & \# & $\%$ \\
\hline Cardiopathy & 1 & 4 & 6 & 4 & 15 & 13,89 \\
\hline Pyloric hypertrophy & 0 & 1 & 3 & 0 & 4 & 3,7 \\
\hline Downs' syndrome & 2 & 2 & 0 & 0 & 4 & 3,7 \\
\hline Cleft palate & 0 & 0 & 1 & 3 & 4 & 3,7 \\
\hline Imperforate anus & 1 & 0 & 0 & 3 & 4 & 3.7 \\
\hline Pyloric stenosis & 3 & 0 & 0 & 0 & 3 & 2,78 \\
\hline Cheilopalatoschisis & 0 & 0 & 1 & 2 & 3 & 2,78 \\
\hline Cryptorquidism & 0 & 1 & 1 & 1 & 3 & 2,78 \\
\hline Renal & 1 & 0 & 1 & 1 & 3 & 2,78 \\
\hline Hip dislocation & 1 & 0 & 0 & 1 & 2 & 1,85 \\
\hline Hydrocephalus & 0 & 1 & 1 & 0 & 2 & 1.85 \\
\hline $\begin{array}{l}\text { Oesophageal } \\
\text { athrepsia }\end{array}$ & 0 & 0 & 1 & 1 & 2 & 1,85 \\
\hline Myelomeningocele & 1 & 0 & 1 & 0 & 2 & 1,85 \\
\hline Hypospadias & 0 & 0 & 0 & 2 & 2 & 1,85 \\
\hline Intestinal athrepsia & 2 & 0 & 0 & 0 & 2 & 1,85 \\
\hline $\begin{array}{l}\text { Cardiopathy and } \\
\text { cryptorquidism }\end{array}$ & 1 & 0 & 1 & 0 & 2 & 1,85 \\
\hline Dextrocardio/cardiop & 1 & 0 & 1 & 0 & 2 & 1,85 \\
\hline $\begin{array}{l}\text { Hydrocephalus/ } \\
\text { myelomeningocele }\end{array}$ & 0 & 1 & 0 & 1 & 2 & 1,85 \\
\hline Sub-total & 14 & 10 & 18 & 19 & 61 & 56,48 \\
\hline $\begin{array}{l}\text { Other malformations } \\
\text { (frequency } 1 \text { each } \\
\text { type) }\end{array}$ & 11 & 3 & 13 & 20 & 47 & 43,52 \\
\hline Total & 25 & 13 & 31 & 39 & 108 & 100 \\
\hline
\end{tabular}

Table 4. Distribution of children having congenital malformations according to system of malformation and year. Cojedes state, 1999-2002

\begin{tabular}{|c|c|c|c|c|c|c|}
\hline \multirow{2}{*}{ System } & \multirow{2}{*}{1999} & \multirow{2}{*}{2000} & \multirow{2}{*}{2001} & \multirow{2}{*}{2002} & \multicolumn{2}{|c|}{ total } \\
\hline & & & & & \# & $\%$ \\
\hline Cardiovascular & 2 & 4 & 9 & 7 & 22 & 20,37 \\
\hline Gastrointestinal tract & 6 & 1 & 5 & 8 & 20 & 18,52 \\
\hline Urogenital & 3 & 1 & 4 & 3 & 11 & 10,19 \\
\hline Face & 1 & 1 & 2 & 5 & 9 & 8,33 \\
\hline Nervous system & 2 & 2 & 3 & 2 & 9 & 8,33 \\
\hline Musculoskeletal & 3 & 1 & 2 & 2 & 8 & 7,41 \\
\hline Chromosomal & 2 & 2 & $\overline{0}$ & 0 & 4 & 3,70 \\
\hline Palate & 0 & 0 & 1 & 3 & 4 & 3,70 \\
\hline Oral cavity & 0 & 0 & 2 & 1 & 3 & 2,78 \\
\hline Lips & 0 & 0 & 1 & 2 & 3 & 2,78 \\
\hline Palatellip/face & D & 0 & 0 & 2 & 2 & 1,85 \\
\hline Cardiovascular/urogenital & 1 & 0 & 1 & 0 & 2 & 1,85 \\
\hline Nervous system / musculoskeletal & 0 & 1 & 1 & 0 & 2 & 1,85 \\
\hline Sub-total & 20 & 13 & 31 & 35 & $9 \overline{9}$ & 91,67 \\
\hline $\begin{array}{l}\text { Other malformations (frequency } 1 \\
\text { each type) }\end{array}$ & 5 & 0 & 0 & 4 & 9 & 8,33 \\
\hline Total & 25 & 13 & 31 & 39 & 108 & 100.00 \\
\hline
\end{tabular}


Table 5. Results of the fitted-GLM

\begin{tabular}{lllll}
\hline Coefficients & Estimate & Std. Error & $z$ value & Pr $(>|z|)$ \\
\hline (Intercept) & $1.780 e+01$ & $2.694 e+02$ & 0.066 & 0.947309 \\
County & $-1.836 e+03$ & $9.501 e+02$ & -1.932 & 0.053339 \\
County*county & $-4.103 e+03$ & $1.215 e+03$ & -3.377 & 0.000732 \\
Date & $-8.669 e-03$ & $1.347 e-01$ & -0.064 & 0.948672 \\
County*date & $9.164 e-01$ & $4.748 e-01$ & 1.930 & 0.053578 \\
County*county*date & $2.054 e+00$ & $6.073 e-01$ & 3.382 & 0.000721 \\
\hline
\end{tabular}

\section{DISCUSSION}

Average prevalence during the 4 years studied $(0,67 \%)$ was consistent with the only other prevalence study (1972-1981) found pertaining to this hospital $(0,72 \%)$. A rate of 13,76 per 1000 inhabitants was found in the same study, being quite higher than that found in the present study (6,74 per 1000 inhabitants) ${ }^{1}$.

Records contained no information about fathers' occupations; there was no information regarding the occupation of 80 of the mothers (74,1\%). However, it is known that parents' potential exposure to agrochemicals can be just environmental or occupational, through air and oral routes or via contaminated work clothing $(6,16)$. Contaminated paternal seminal fluid can lead to eventual effects on a foetus (17). The literature report women living in communities having drinking-water contaminated by pesticides, leading to an increased risk of retarding intrauterine growth. This has been shown with herbicides such as cyanazine, metolachlor and atrazine (the latter has been reported as being used in the region being studied) (4). However, it is not known whether the parents' exposure was rather small and negative results should therefore be interpreted with caution.

The study had some limitations.

- The case-histories were not complete. There was an absence of data regarding potential parents' exposure, which could have led to misclassification. It is very important that both maternal and paternal exposure be considered. If a toxin is present in paternal seminal fluid then intercourse during pregnancy can lead to systemic maternal absorption of such toxin and an eventual effect on the foetus (16).

\footnotetext{
${ }^{1}$ Lozada O. [Malformaciones congénitas en el Hospital General de San Carlos. 1972-1981]. Graduate Thesis. Medicine School. San Carlos extention. University of Carabobo. 1985. Located at: Health Sciences Faculty library. UC. Valencia. Venezuela.
} 
- The timing of exposure is also important when assessing pesticides' reproductive and developmental effects; we lacked such information.

Table 5 shows the different significant associations found in each county studied, in spite of previous uncertainties in establishing a causal association between $\mathrm{BD}$ and potential pesticide exposure. It also shows that the number of BD increased exponentially throughout the years being studied. Other important contributing factors to BD cannot be excluded such as socio-economic, nutritional, multi-exposure and medication factors; these will be considered in a future study. A more in-depth assessment of exposure, accompanied by epidemiological studies, is still needed for characterising the risk of exposure to pesticides in terms of birth outcomes in the given area •

\section{REFERENCES}

1. Rojas M, Weiss P, Rodríguez M, Agreda O. Determinants of pesticide poisonings in the central-western region of Venezuela. Chinese Society of Toxicology 2003; 7(4):16-16.

2. Rojas M, Reid J. Pesticide exposure in a farming village in a developing country. Archives of Environmental Health Nov-Dec 1999; 54(6):430-435.

3. Rivero E, Rincón R, Rojas M, González S. Exposición ocupacional a plaguicidas en una comunidad agrícola del Estado Lara, Venezuela. Salud de los Trabajadores Julio 1997;5(2):93-98.

4. Solomon G, Ogunseitan OA, J Kirsch J. Pesticides and human health. A resource for health care professionals. 2000. Chapter 7: Reproductive and developmental effects of pesticides. Physicians for Social Responsibility. Santa Monica, Ca. pp 39-41.

5. Zhu JL, Hjollund NH, Nybo Andersen AM, Olsen J. Occupational exposure to pesticides and pregnancy outcomes in gardeners and farmers: A study within the Danish national birth cohort. JOEM April 2006; 48(4):347-352.

6. Rull RP, Ritz B, Shaw GM. Neural tube defects and maternal residential proximity to agricultural pesticide. Applications. Am J Epidemiol 2006; 163(8): 743-753.

7. Lacasaña M, Vázquez-Grameix H, Borja-Aburto VH, Blanco-MuñozJ, Romieu I, AguilarGarduño C., et al. Maternal and paternal occupational exposure to agricultural work and the risk of anencephaly. Occup Environ Med 2006; 63(10):649-656.

8. Ronda E, Regidor E, Garcia AM, Dominguez V. Association between congenital abnormalities and paternal exposure to agricultural pesticides depending on mother's employment status. JOEM 2005; 47(8): 826-828. 
9. Medina-Carrillo L, Rivas-Solis F, Fernández-Arguelles R. Riesgo para malformaciones congénitas en mujeres gestantes expuestas a plaguicidas en el estado de Nayarit, México. Ginecologia y Obstetricia de Mexico Nov 2002; 20(11): 538-544.

10. Division of Epidemiology and Health Assessment, Florida Department of Health. Collier County Health Department investigation into the occurrence of congenital malformations in Immokalee, Collier County, Florida 2005; October 12, 2005.

11. OPS/OMS. CIE-10. Clasificación estadística internacional de enfermedades y problemas relacionados con la salud. 10ª revisión. Vol. 1. Pub. Cientifica No. 554. Washington DC. 1997.

12. Compendium of pesticides common names [Internet]. Available at: http:// www.alanwood.net/pesticides). Consulted March 2007.

13. PAN pesticides database [Internet]. Available at: http://www.pesticideinfo.org. Consulted March 2007.

14. Anzola L. Índice Agropecuario 2005. 30th edition. Maracay. Venezuela. Agroisleña; 2005.

15. McCullagh P, Nelder J. Generalized linear models. Second Edition (Monographs on Statistics and Applied Probability). London: Chapman and Hall/CRC; 1999.

16. Knishkowy B, Baker EL. Transmission of occupational disease to family contacts. Am J Ind Med 1986; 9(6):543-550.

17. Sterling TD, Arundel AV. Health effects of phenoxy herbicides. A review. Scand J Work Environ Health 1986; 12(3):161-173.

18. Singh ND, Sharma AK, Dwivedi P, Patil RD, Kumar M. Citrinin and endosulfan induced teratogenic effects in Wistar rats. J Appl Toxicol 2007 Mar-Apr; 27(2):143-51.

19. Kim JC, Shin JY, Yang YS, Shin DH, Moon CJ, Kim SH, Park SC, Kim YB, Kim HC, Chung MK. Evaluation of developmental toxicity of Amitraz in Sprague-Dawley rats. Arch Environ Contam Toxicol 2007 Jan; 52(1):137-44. 